$\mathrm{DOE} / \mathrm{MC} / 29120-95 / \mathrm{C} 0416$

$$
\text { Conf }-9411149--24
$$

\title{
REVIEW OF THE VORTEC SOIL REMEDIATION DEMONSTRATION PROGRAM
}

Authors:

Dr. John S. Patten

\section{Contractor:}

Vortec Corporation

3770 Ridge Pike

Collegeville, Pennsylvania 19426

\section{Contract Number:}

DE-AC21-92MC29120

\section{Conference Title:}

Proceedings of Opportunity '95 - Environmental Technology

Through Small Business

\section{Conference Location:}

Morgantown, West Virginia

\section{Conference Dates:}

November 16 - 17, 1994

\section{Conference Sponsor:}

U.S. Department of Energy - Morgantown Energy Technology Center 


\section{DISCLAIMER}

This report was prepared as an account of work sponsored by an agency of the United States Government. Neither the United States Government nor any agency thereof, nor any of their employees, makes any warranty, express or implied, or assumes any legal liability or responsibility for the accuracy, completeness, or usefulness of any information, apparatus, product, or process disclosed, or represents that its use would not infringe privately owned rights. Reference herein to any specific commercial product, process, or service by trade name, trademark, manufacturer, or otherwise does not necessarily constitute or imply its endorsement, recommendation, or favoring by the United States Government or any agency thereof. The views and opinions of authors expressed herein do not necessarily state or reflect those of the United States Government or any agency thereof.

This report has been reproduced directly from the best available copy.

Available to DOE and DOE contractors from the Office of Scientific and Technical Information, 175 Oak Ridge Turnpike, Oak Ridge, TN 37831; prices available at (615) 576-8401.

Available to the public from the National Technical Information Service, U.S. Department of Commerce, 5285 Port Royal Road, Springfield, VA 22161; phone orders accepted at (703) 487-4650. 


\section{DISCLAIMER}

Portions of this document may be illegible in electronic image products. Images are produced from the best available original document. 
CONTRACT INFORMATION

Contract Number

Contractor

Contractor Project Manager

Principal Investigators

METC Project Manager

Period of Performance

Schedule and Milestones
DE-AC21-92MC29120

Vortec Corporation 3770 Ridge Pike Collegeville, PA 19426

(610) 489-2255

Dr. John S. Patten

Dr. John S. Patten

Clifford P. Carpenter II

March 1994 to February 1996

\begin{tabular}{|c|c|c|c|c|c|c|c|c|c|c|}
\hline & & & $\mathrm{CY}$ & & & & & & & \\
\hline & M & A & $\mathbf{M}$ & $\mathrm{J}$ & $\mathrm{J}$ & A & $S$ & 0 & $\mathrm{~N}$ & $\mathrm{D}$ \\
\hline NEPA Documentation & & $\mathrm{X}$ & & & & & & & ' & \\
\hline Site Selection & & $\mathrm{X}$ & & & & & & & $\therefore$ & \\
\hline Plant Design & & & & & & & & & : & $X$ \\
\hline Technology Plan & & & & & 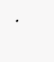 & & & & & $\mathrm{X}$ \\
\hline
\end{tabular}




\subsection{CONTRACT INFORMATION}

Vortec is successfully completing Phase 2 of the "Innovative Fossil Fuel Fired Vitrification Technology for Soil Remediation" program under Contract No. DE-AC21-92MC29120 with the Department of Energy (DOE) Morgantown Energy Technology Center (METC). Vortec contacted six DOE sites during Phase 1 to determine their interest in hosting the demonstration plant. DOE Richland Operation indicated, in a letter from Roger Freeberg to Paul Hart, that DOR/RL would support the demonstration of the CMS technology by providing site support and contaminated materials in the form of fines generated from the soil washing experiments being conducted in the 100 area at Hanford.

Hanford supplied the soil characteristics of these fine materials and these data, in conjunction with other site specific health and safety considerations, established the design requirements for a 25 TPD vitrification demonstration plant. A final design and cost studies are being completed for a transportable demonstration plant. The baseline plant design has the capacity to process 25 tons per day (TPD) of dried and sized soil. The system configuration includes subsystems for soil preparation, heating and melting, and for air pollution control. The installed costs, that is, the cost to purchase and install the equipment for the Demonstration Plant, is estimated to be approximately $\$ 6-7$ million. Estimated time to procure and construct the demonstration plant is approximately nine months with an additional three months required to shakedown, start-up, and complete the 30 day test. The total program cost that includes procurement, operation, and support engineering during the demonstration testing is estimated to be approximately $\$ 12$ million.

Verification testing is being conducted at Vortec's Test Facility located at the University of Pittsburgh's Applied Research Center (U-PARC) in Harmarville PA. The Hanford soil was simulated using the composition data supplied by Hanford, and was spiked with Resource Conservation and Recovery Act (RCRA) metals surrogates, an organic contaminant, and surrogate radionuclides. The sampling of the effluent and influent streams taken during the tests confirmed that virtually all of the refractory radionuclides were retained in the glass and would not leach to the environment-as confirmed by both Product Consistency Tests (PCT) and Toxicity Characteristic Leaching Procedure (TCLP) testing. The organic contaminant, anthracene, was destroyed during testing with a Destruction and Removal Efficiency (DRE) of at least 99.99\%. Semi-volatile RCRA metal surrogates were captured by the Air Pollution Control (APC) system, and data on the amount and the chemical composition of the particulate were established for use in the APC system design.

\subsection{PROGRAM OBJECTIVES}

The principal objective of the METC/Vortec program is to develop and demonstrate the effectiveness of the Vortec CMS in remediating soils contaminated with hazardous materials and/or low levels of radionuclides. To convincingly demonstrate the CMS's capability, a Demonstration Plant will be constructed and operated at a DOE site that has a need for the remediation of contaminated soil. The following objectives will be met during the program.

1. Establish the glass chemistry requirements to achieve vitrification of contaminated soils found at the selected DOE site; that is, given a particular site's soil, determine how its oxide composition must be modified to produce a vitrified product that will immobilize contaminants over the long-term.

2. Complete the design of a fully integrated soil vitrification demonstration plant with a capacity to process 25 TPD of soil.

3. Establish the cost of a fully integrated soil demonstration plant with a capacity to process 25 TPD of soil.

4. Construct and operate a fully integrated demonstration plant.

5. Analyze all influent and effluent streams to establish the partitioning of contaminants and to demonstrate 
compliance with all applicable health, safety, and environmental requirements.

6. Demonstrate that the CMS technology has the capability to produce a vitrified product that will immobilize the hazardous and radionuclide materials consistent with the needs of the specific DOE waste repositories.

\subsection{BACKGROUND INFORMATION}

The Department of Energy's goal to clean-up its nuclear complex by the year 2019 requires the development of innovative technologies to convert soils contaminated by hazardous and/or radioactive wastes to forms which can be readily disposed in accordance with current waste disposal methods. These technologies must be able to accomplish this task with minimum public and occupational health risks, with minimum environmental risks, and in a timely and economical manner. Additionally, the technologies must transform the hazardous and/or radioactive waste into a form which is considered non-hazardous; which has long-term stability to prevent migration of radionuclides, and can thus be disposed in an environmentally safe manner; and which satisfies all federal, state, and local emissions regulations. It is imperative that the technology not present any major obstacles to its own safe decontamination and decommissioning. Finally, the final waste form produced must be very stable since some of materials have very long half-lives that may greatly exceed the capability of institutional controls to protect the environment.

The unique features of the CMS technology should make it a particularly cost-effective process for the vitrification of soils, sediments; sludges, and mill tailings containing organic, metallic, and/or radioactive contaminants. Many of the benefits of the CMS technology recognized by the glass and hazardous waste management industry would also apply to DOE's ER\&WM needs. Benefits with respect to DOE's needs would include:

1. The ability to produce a product which immobilizes heavy metals, toxic inorganics, and radionuclides over very long periods without the need for institutional controls.

2. Its flexibility with respect to the types of materials which can be processed allows for accommodation of variations in feedstock composition and provides for a broad range of hazardous material applications.

3. The potential for oxidizing and vitrifying materials introduced as a slurry provides the capability for mixing contaminated or waste oils with various types of hazardous solids, such as soils, soil wash process sediments, and mill tailings. The CMS has demonstrated the capability of processing soil-water slurry and water soluble waste streams.

4. The high temperature process components have water-cooled steel walls providing for a sealed process which can be operated at negative pressure to prevent leakage of contaminated gases to the atmosphere.

5. The water-cooled components can continue to operate in the event that unusual wear or separation of refractory occurs, until such time as the unit can be safely shut down.

6. Its small physical size reduces the decommissioning costs of the process equipment at the end of its useful life.

Vortec, during the first two phases of this program, has demonstrated the CMS technology's ability to remediate surrogate soils. During Phase 2 of the program, surrogate soils from Hanford's 116-D-1B and 116-F-4 sites were defined using data obtained from the site's ER\&WM organizations. The soil was spiked with surrogate heavy metals and radionuclides and vitrified at the U-PARC facility. The vitrified product produced during the first two tests passed both the TCLP test for leachability of the heavy metals, and possessed a superior stability as demonstrated by the PCT test.

During this phase of the program, the final design and cost estimate for a 25 TPD system 
were also developed. The baseline plant design included a feedstock preparation subsystem combining the soil washing fines (average moisture content of $30 \%$ ) with glass making additives, the CMS subsystem, and an air pollution control (APC) subsystem that cleans the flue gas using a wet electrostatic precipitator (WESP).

The plant design has been reviewed by both the Hanford's Health and Safety organization and the Washington State Department of Ecology. Both organizations have given preliminary approval for construction and operation.

\section{DESCRIPTION OF VORTEC'S COMBUSTION AND MELTING SYSTEM}

The following section will describe the CMS process. Section 4.0, Results, will discuss the Demonstration Plant as it is now defined.

\section{PROCESS DESCRIPTION AND OPERATING CONDITIONS}

The primary components of the basic CMS are a counter-rotating vortex (CRV) combustor and a cyclone melter. An artist's rendering of the basic CMS concept is shown in Figure 3.0-1. A unique feature of the process is the rapid suspension heating and oxidation of feedstock materials in the CRV combustor prior to the physical and chemical melting processes which occur within the cyclone melter. The use of the Vortec CRV combustor in conjunction with a cyclone melter distinguishes the Vortec combustion and melting technology from other types of cyclone combustion systems. In the CMS process, granular glass-forming ingredients and other feedstocks are introduced into the top region of the CRV combustor along with fuel and combustion air. As a result of the intense counterrotating vortex mixing, it is possible to achieve stable combustion in the presence of large quantities of inert particulate matter (solids-to-gas mass ratios on the order of $1: 1$ ). Both convection and radiation heat transfer mechanisms contribute to the rapid heating of the feedstock materials within the CRV combustor. Any organic

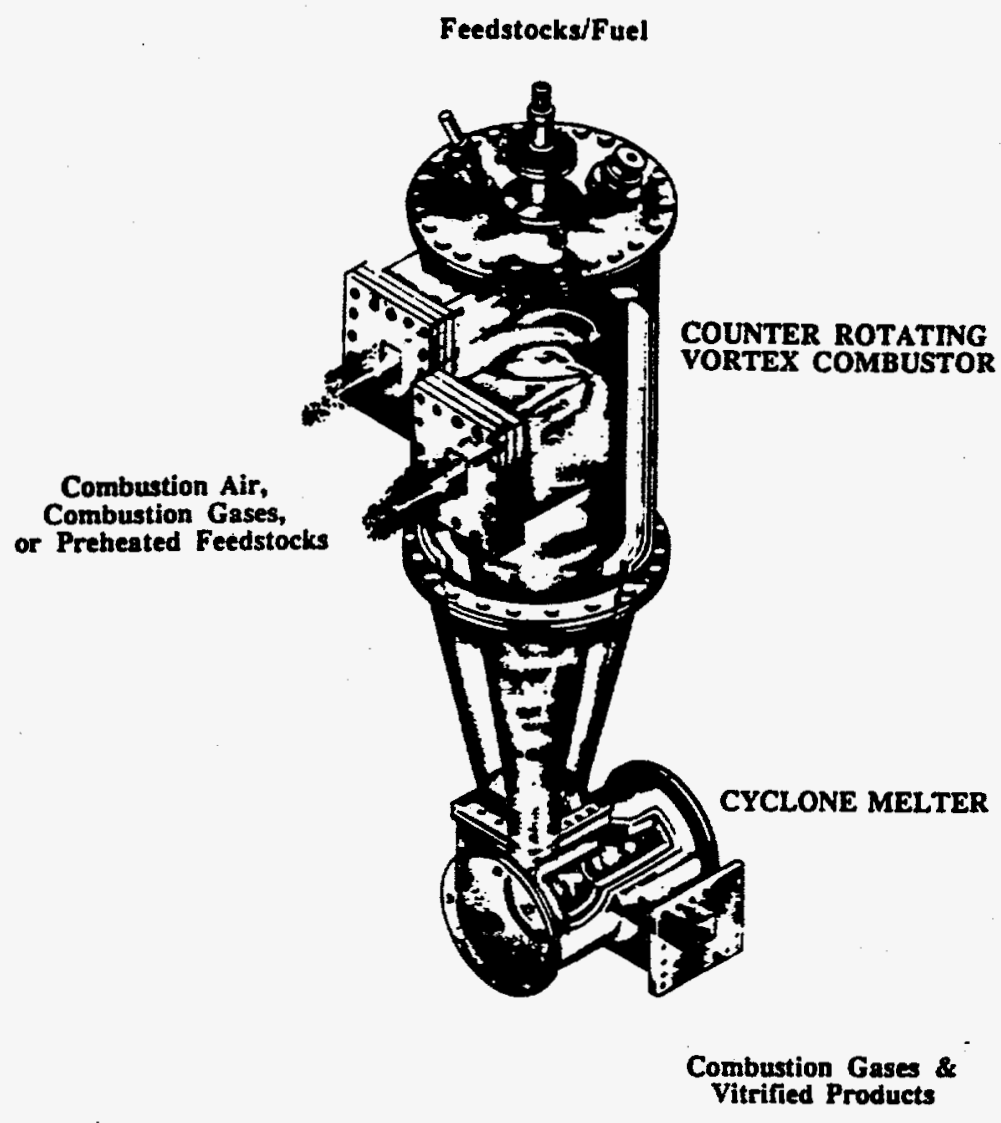

Figure 3.0-1. Artist Rendering of Basic Combustion/Melting System

contaminants in the feedstocks are also effectively oxidized.

The melted product formed in the cyclone melter, and the combustion products, exit through a tangential channel and enter a separator/reservoir (not shown in the figure) where a pool of the melted material is collected. The vitrified material exits the reservoir through a bottom or side tap, and the flue gases exhaust to a water quench/electrostatic precipitator assembly or an optional heat recovery unit for combustion air preheating. 
The flue gas exiting the separator/reservoir is treated in an air pollution control assembly prior to being exhausted out the stack. As a result of the high thermal efficiency of the Vortec CMS, the flue gas flow rates are relatively modest. Because the temperature and composition of the vitrified product can be closely controlled, the amount of process fuming (volatile carryover) can also be minimized.

The average gas-solids suspension temperature leaving the CRV combustor is typically on the order of $2000^{\circ} \mathrm{F}$ to $2700^{\circ} \mathrm{F}$, depending on the product being vitrified. The process temperatures in the cyclone melter are typically in the range of $2000^{\circ} \mathrm{F}$ to $3000^{\circ} \mathrm{F}$, depending on the melting characteristics of the feedstock being processed. The nitrogen oxide emissions have been found to be substantially lower than those which occur in conventional cyclone combustors. Excess air levels are typically in the range of 5 to $20 \%$ depending on the makeup and the nature of the feedstock being processed.

Heat rates demonstrated by the Vortec pilot scale facility typically ranged between 3.5 and 6 million Btu/ton at a glass production rate of 15 TPD. This heat rate is $50 \%$ to $80 \%$ lower than heat rates for conventional gas-fired glass melting at similar capacity. The energy savings are primarily due to more efficient heating of the glass ingredients in suspension by the products of combustion and lower structural heat losses due to the small physical size of the process components. The CMS can also accommodate the use of a variety of fuels, such as oil and coal-derived fuels, and even organic waste materials. Recent tests, using Hanford's low level tank waste simulant, demonstrated the CRV combustor's ability to successfully process a feedstream containing up to $30 \%$ water.

Most of the tests conducted to date have used a dry, shredded, or pulverized (less than 600 microns particle size) feedstock pneumatically transported and injected into the CMS, and have used natural gas and/or coal as the fuel. During the Phase 1 tests conducted by this program, a feedstock, with a top particle size of 1 millimeter in diameter, was vitrified using the CMS process. When using a feedstock with this top size distribution, additional residence time is required to produce a fully reacted glass.

The CMS pilot system has demonstrated $\mathrm{NO}_{\mathrm{x}}$ emissions of less than 4 pounds per ton of vitrified product, meeting the California emission standard for glass melting furnaces-currently the most stringent in the United States. With natural gas as the primary fuel, the $\mathrm{NO}_{\mathrm{x}}$ emissions, calculated as $\mathrm{NO}_{2}$, have typically been approximately 2 pounds per ton of product. Rapid temperature quenching of the combustion products by the inert solid particles and staged combustion are the primary means of limiting $\mathrm{NO}_{\mathrm{x}}$ emissions. Tests conducted for Hanford using a high nitrate concentration tank simulant resulted in no visible plume leaving the pilot plant's stack.

The CMS has demonstrated uncontrolled emissions levels of less than $0.5 \%$ of feed materials which did not contain low temperature volatiles, such as utility flyash. For materials containing heavy metals and other volatiles, such as MSWI flyash and fiberglass waste, the uncontrolled emissions levels have typically been in the range from $1 \%$ to $2 \%$. As part of the METC program, Vortec has demonstrated a procedure for recycling the volatile materials into the glass after the glass has left the high temperature region of the combustor.

\section{Previous ReSEARCH ACCOMPLISHED AT THE U-PARC FACILITY}

After four years of design evolution under various DOE and EPA programs, the CMS is completely operational at the U-PARC test facility. Vortec's system has demonstrated the production of glass and the vitrification of a variety of feedstocks, including:

- Utility flyash,

- Fiberglass waste with organic contaminants,

- EPA surrogate soils,

- Municipal solid waste incinerator (MSWI) flyash, and

- Dusts containing heavy metals and organic materials. 


\subsection{RESULTS}

Vortec has successfully completed the verification testing and final baseline plant design required in Phase 2 of this program. Vortec will continue the development, construction, and operation of the CMS Demonstration Plant during Phase 3 . Vortec believes that the CMS technology is at the stage of development that will result in a mature process that is directly applicable to a large number of DOE Environmental Restoration and Waste Management (ER\&WM) needs. Vortec is developing the CMS technology to commercial readiness, with the intention of economically meeting all public, occupational, and environmental health and safety requirements for remediation technology. Commercial offerings of the CMS technology, in plant sizes up to 200 TPD, have been made during the last year.

The initial site selected by DOE/METC and Vortec was Hanford's 100 area where contaminated soil fines from the soil washing experiments were made available as feedstock.

\subsection{Test Program-Phase 2 Results Summary}

The verification testing in Phase 2 has been completed. Preliminary data generated during the first test series (Tests 1 and 2, conducted in June 1994) confirmed that the CMS can successfully vitrify contaminated Hanford soils. The vitrified products passed the TCLP test, and the vitrified product was also analyzed by the PCT test procedure. The results of the PCT test indicate that the chemical durability of the vitrified product exceeds the present specifications for a nuclear waste glass. The current PCT specification for nuclear waste glasses is a weight loss of 1 gram of glass $/ \mathrm{m}^{2} /$ day. The Nanormalized PCT results for the vitrified product produced during Phase 2 testing were 0.0053 and 0.0032 grams of glass $/ \mathrm{m}^{2} /$ day for Test 1 and Test 2 , respectively.

The elemental mass balances performed on the surrogate heavy metal and radionuclide contaminants closed for each of the contaminants in the feedstock (to within approximately 85-
$110 \%)$. The partitioning of the non-volatile contaminants to the vitrified product are typical of those observed in previous testing of contaminated materials in the Vortec CMS$99+\%$ of the $\mathrm{Sr}, \mathrm{V}, \mathrm{Co}$, and $\mathrm{Ce}$ and $90+\%$ of the $\mathrm{Cr}$ are found in the vitrified product.

The partitioning among the effluent streams is dependent upon the halogen $(\mathrm{F}$ and $\mathrm{Cl}$ ) content of the feedstream, the operating temperature of the CMS, and may also depend on the original chemical form (metallic, oxide, chloride, etc.) of the contaminants in the soil. The lead and cadmium were added to the simulated soil matrix as oxides, and the cesium was added in its carbonate form. Since there is no chlorine in the soil, the chemical composition of the surrogates did not pose a problem.

The average glass temperatures during Tests 1 and 2 were approximately $2225^{\circ} \mathrm{F}$ and $2340^{\circ} \mathrm{F}$, respectively.

The partitioning of the semi-volatile contaminants to the vitrified product were $32-36 \%$ of the Cd, $80 \%$ of the lead, and $75-80 \%$ of the cesium. Table 4.1-1 presents the preliminary data indicating the partitioning of elements of concern between the flue gas and vitrified product streams for the first test series using the surrogate Hanford soil. Additional testing is under way using fewer glass fluxes in the feedstock. Preliminary results from these tests (test numbers 4 and 5) are in agreement with the results presented here.

\subsection{Design Program-Integrated Demonstration Plant}

A principal function of Phase 2 is to complete the final design of the demonstration plant to be constructed at the Hanford site. Discussions with the Hanford's Environmental Restoration personnel (Eric Goller, Joan Woolard, and John Ludowise) indicated that soil fines from the soil washing treatability test would be the feed material for the demonstration test. The vitrification of the fines from the soil washing operation essentially completed the soil remediation process in the 100 area, since the radionuclides had been collected, treated, and immobilized. 
Table 4.1-1. Partitioning of Element among Effluent Streams

\begin{tabular}{|l|c|c|c|c|}
\hline Specie & $\begin{array}{c}\text { Test 1 } \\
\text { Glass }\end{array}$ & $\begin{array}{c}\text { Test 1 } \\
\text { Flue Gas }\end{array}$ & $\begin{array}{c}\text { Test 2 } \\
\text { Glass } \\
\%\end{array}$ & $\begin{array}{c}\text { Test 2 } \\
\text { Fue Gas } \\
\%\end{array}$ \\
\hline $\mathrm{Na}$ & 99.76 & 0.24 & 99.69 & 0.31 \\
$\mathrm{Si}$ & 100.00 & 0.00 & 100.00 & 0.00 \\
$\mathrm{Ca}$ & 100.00 & 0.00 & 99.94 & 0.06 \\
$\mathrm{Al}$ & 100.00 & 0.00 & 100.00 & 0.00 \\
$\mathrm{Fe}$ & 100.00 & $\mathrm{NT}$ & 100.00 & $\mathrm{NT}$ \\
$\mathrm{K}$ & 99.47 & 0.53 & 99.32 & 0.68 \\
$\mathrm{Cd}$ & 36.46 & 63.54 & 32.69 & 67.31 \\
$\mathrm{Cr}$ & 89.75 & 10.25 & 98.67 & 1.33 \\
$\mathrm{~Pb}$ & 79.33 & 20.67 & 80.47 & 19.53 \\
$\mathrm{Sr}$ & 99.67 & 0.33 & 99.64 & 0.36 \\
$\mathrm{~V}$ & 99.50 & 0.50 & 99.33 & 0.67 \\
$\mathrm{Co}$ & 99.57 & 0.43 & 99.59 & 0.41 \\
$\mathrm{Ce}$ & 99.98 & 0.02 & 99.98 & 0.02 \\
$\mathrm{Cs}$ & 75.00 & 25.00 & 80.66 & 19.34 \\
\hline
\end{tabular}

NT $\equiv$ Sample was not analyzed for this element.

Characterization of the fine material indicated that a significant amount of the radionuclides were retained by the fines, that they would have an average moisture content of $30 \%$ after washing, and the mean size was less than the 600 microns. As a result, the baseline plant system requirements, that define the plant, will require the processing of dried soil ( $5 \%$ moisture) having a maximum particle size of 600 microns. The following paragraphs will describe the plant in some detail. However, it should be pointed out that the plant design is modular and transportable. It is fully intended that the plant as designed has the capability of processing a variety of materials by the addition of suitable subsystems, that the plant capacity be easily expanded by at least a factor of two by the use of oxygen enriched air as a oxidant, and that the plant design include pollution control systems needed to meet the local health, safety, and environmental codes.

\subsubsection{System Requirements}

The system requirements for the Demonstration Plant to be operated at Hanford's 100 area are as follows:
1. Waste soil input will be approximately 25 TPD of dried and sized soil.

2. The demonstration plant will be transportable, allowing for its use at multiple DOE sites and/or multiple locations at a single site. Process equipment will be skid-mounted which can be either mounted to concrete pad foundations or other transportable foundation structures.

3. The demonstration plant will be capable of processing mixed wastes. Mixed wastes in this case are soils, sediments, and/or sludges contaminated with hazardous wastes and low-level radioactive wastes. At Hanford, the soil does not contain organic materials (other than some vegetation). For the Demonstration Plant designed for the Hanford soil, no organic contamination (solvents, fuels, etc.) are present and, therefore, the acid gas scrubbing subassembly needed for acid gas $(\mathrm{HCl})$ neutralization is not included. Both volatile (cesium) and nonvolatile (uranium and plutonium) radionuclides may be present in the soil waste stream.

4. The entering waste stream will be fed, in dry form, to the CRV combustor with a particle size no greater than 600 microns and a moisture content that enables the material to flow freely (approximately 0 to 10 percent). Since the soil fines had a moisture content of $30 \%$, a drier was included as part of the soil preparation subsystem. Since fines were to be the only material used during the demonstration, the grinding loop was not included in the system requirements.

5. The APC subsystem will be required to meet DOE/EPA standards for the removal of hazardous material and radionuclides. For Hanford, a single Wet Electrostatic Precipitator (WESP) was specified to meet the requirements of the site's health, safety, and environmental regulations. 
6. Residual material regenerated as a result of testing will be disposed on-site, or at an approved DOE low-level radioactive waste-disposal demonstration plant, and will be the responsibility of the DOE demonstration site. These streams may include but are not limited to:

$$
\begin{array}{ll}
\text { - } & \text { Personnel protective } \\
\text { - } & \text { HEPuipment } \\
\text { - } & \text { Treated scrubber/ESP water } \\
\text { (a slip stream is required to } \\
\text { control particulate build-up) } \\
\text { - Spent ion exchange } \\
\text { equipment }
\end{array}
$$

Vitrified product will be returned to the area on the site from which it was removed or be placed in a repository as directed by the site personnel.

7. It is assumed that the DOE site selected is a CERCLA site and is included on EPA's National Priorities List (NPL). CERCLA hazardous waste sites do not require permits for performing remedial activities (although the substantive requirements of the permit must be met). It is further assumed that initial testing (the 30 day demonstration) will be performed with CERCLA hazardous waste only, thereby minimizing requirements for EPA or state permits. When radioactive wastes are processed, additional permitting requirements may be necessary.

\subsubsection{Heat and Material Balances}

A schematic system configuration diagram of the 25 TPD demonstration plant is included as Figure 4.2-1. The schematic helps to understand the flow of the process and to define the interface requirements. Selected state points are indicated in Figure 4.2-1 and listed in Table 4.2-1.

As indicated in Table 4.2-1, soil combined with glass making additives are fed to the combustor at a rate of approximately
$3,116 \mathrm{lbs} / \mathrm{hr}$. Glass is produced at a rate of $2,359 \mathrm{lbs} / \mathrm{hr}$, while the flue gas clean-up system receives $19,676 \mathrm{lbs} / \mathrm{hr}$ at a temperature of $1742^{\circ} \mathrm{F}$. Exhaust gas flow rate with the quench water added increases to $25,745 \mathrm{lb} / \mathrm{hr}$.

\section{Table 4.2-1. Heat and Mass Balance}

\begin{tabular}{|l|c|l|}
\hline & Temperature (F) & \multicolumn{1}{|c|}{ (Mass flow } \\
(ROUNDSAR)
\end{tabular}

\subsubsection{Demonstration Plant-System Description}

The demonstration plant has been designed as a transportable system; that is, the individual components of the process have the capability to be transported by truck to the site, erected, and when operation is complete, dismantled, decontaminated, loaded back onto trucks, and hauled off-site.

A computer generated isometric drawing of the plant arrangement in shown in Figure 4.2-2.

As is indicated in the system diagram Figure 4.2-1, contaminated soil is first transported by DOE/RL in B-25 boxes from various areas at the Hanford site to the vitrification facility. There is always at least a three day supply of the material in the storage area. The storage area is located in a position which minimizes exposure to the personnel in the rest of the facility but is contiguous to the facility to minimize transport from the bin to the soil loading facility.

Soil samples collected prior to the 30 day demonstration test will be used to determine the batch composition. The system 
will have the capability to process contaminated soil with a moisture content up to $30 \%$.

\section{Feed Preparation System}

The contaminated material is moved to the site in B-25 boxes. The material is then emptied from the boxes into the 20 tons capacity feed hopper by a specially modified loader. The hopper is within a ventilated fabric enclosure used to reduce fugitive dust emissions to the surroundings while dumping the soil. The process of vitrifying the soil begins in the Feed Preparation Subsystem. It consists of:

(1) transportation of soil to the hopper for introduction to the feed preparation system, and

(2) a drying and a screening operation to assure that the material is the proper size and moisture content.

To preclude the escape of dust particles when dumping or transporting the soil, all the conveying systems will be designed with an enclosure and operate under negative pressure. In addition, all hoppers and transfer points (dumping points) will also be enclosed and will be under negative pressure. The dust laden air from these devices will pass through a dust collector for particle removal. Solids collected in the dust collector will be transported back into the system. Discharge from the dust collector will pass through a parallel pass HEPA filter system.

The sized and dried soil is transported to a storage silo. Glass making additives are mixed with the soil. Additives (limestone for vitrification of the Hanford soil) are used to aid in glass forming, obtaining the proper glass properties, or modifying the temperature-viscosity curve. The blending system consists of storage silos and pneumatic feed system for the delivery of the soil and limestone to a blend tank. Batch mixing precedes feeding into the Combustion and Melting System.

\section{Combustion and Melting System}

The CMS components consist of a counter-rotating vortex (CRV) combustor, a cyclone melter $(\mathrm{CM})$, a separator/reservoir, and a heat recovery unit (recuperator).

The prepared feedstock is introduced into the CRV combustor through injectors located at the top of the combustor. Combustion air, which has been heated by waste heat in the recuperator, is mixed with fuel (propane) in the inlet arms of the combustor. Auto ignition occurs as the fuel air mixture enters the high temperature region of the combustor, and the resulting combustion products raise the temperature of the feedstock as it enters. Heated feedstock flows through the CRV combustor to the Cyclone Melter, the feedstock reacts in the liquid layer deposited on the walls of the CM, producing the glass. The radionuclides and heavy metals are permanently bonded into the glass matrix. The glass product and the exhaust gases exit the CM through a tangential exit channel and enter a glass/gas separation assembly (separator/reservoir).

The primary functions of the separator/reservoir are to separate the combustion products from the melted material and to provide an interface with a vitrified product handling system. The hot exhaust products exit through an exhaust port which is the interface for the recuperator. The recuperator utilizes the waste heat to preheat combustion air going to the CMS.

Molten glass flows out the separator/reservoir to the Vitrified Product Handling System. 


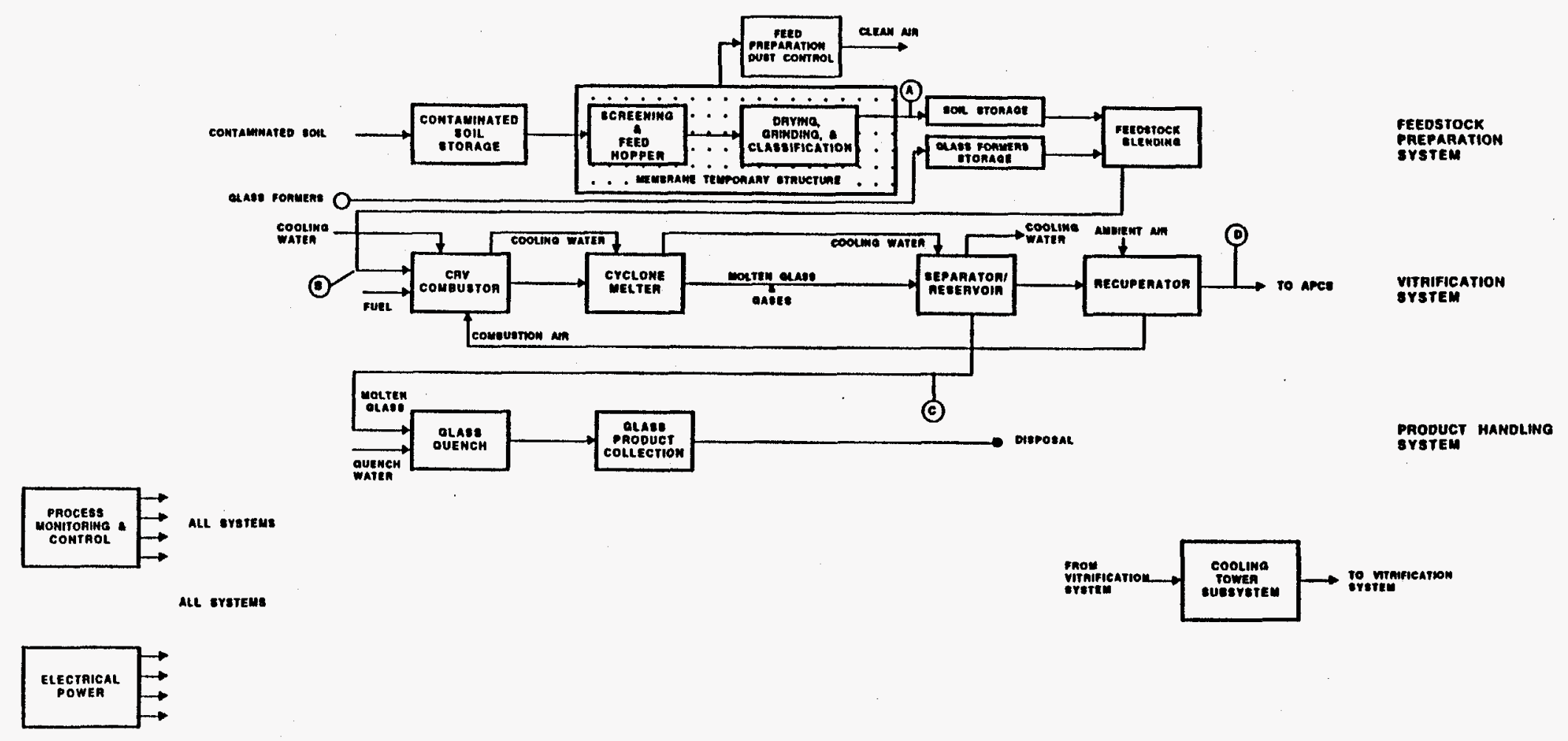

Figure 4.2-1. System Configuration Diagram Sheet 1 of 2 


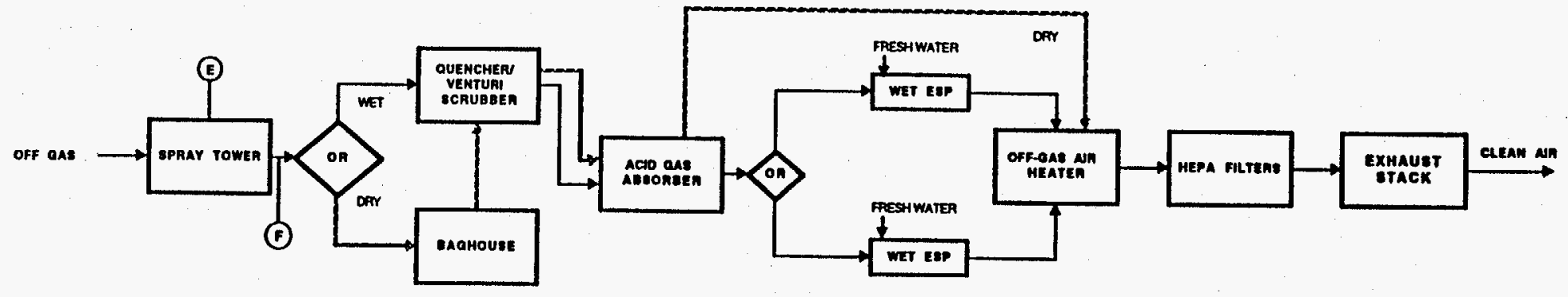

Figure 4.2-1. System Configuration Diagram Sheet 2 of 2 


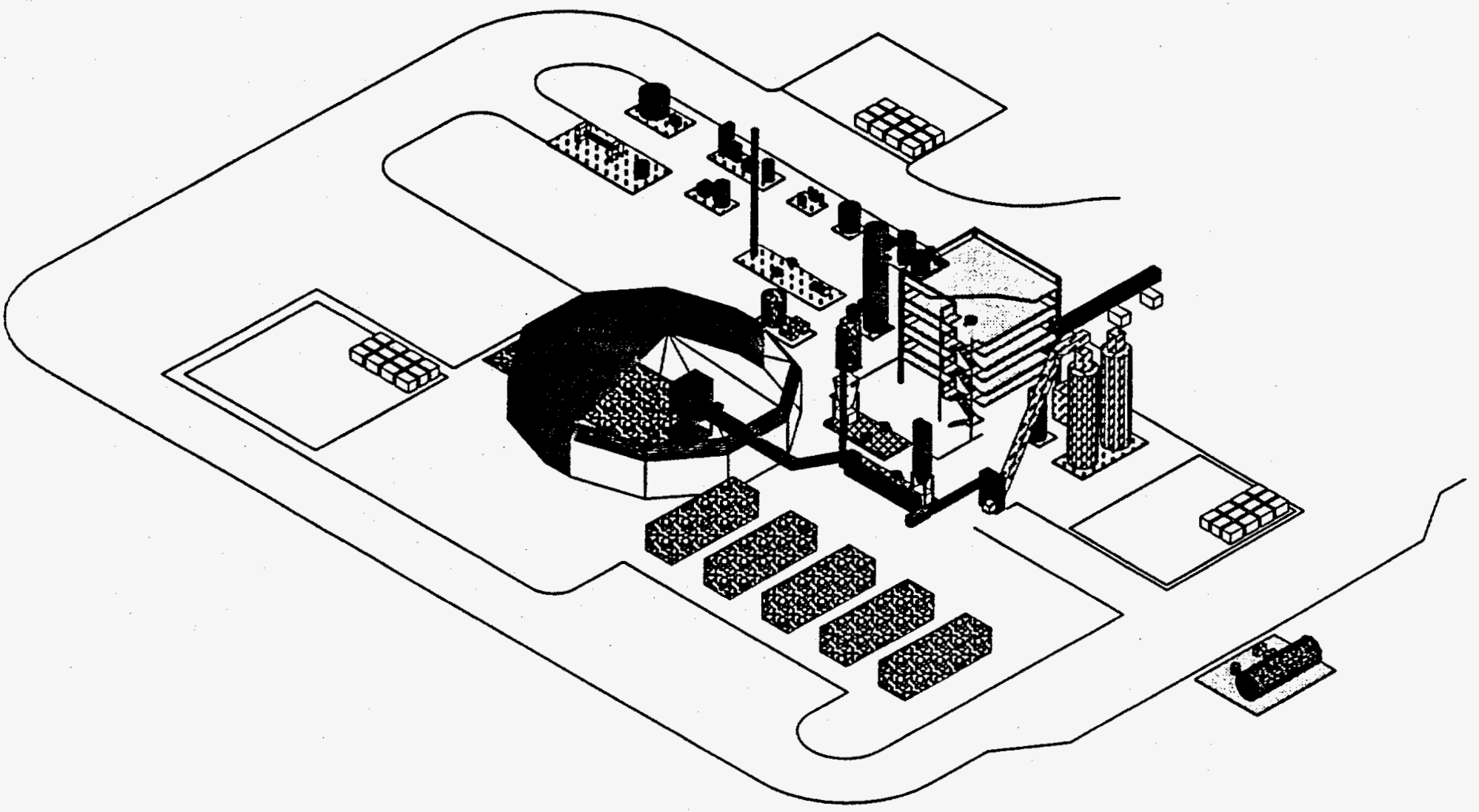

Figure 4.2-2. Isometric Drawing of Plant Arrangement 


\section{Vitrified Product Handling System}

The molten product from the CMS will be water quenched to produce a cullet approximately $1 / 8$ " in average size. The cullet will be transported by conveyor to B25 boxes. The B- 25 boxes, when full, will be moved to a pick-up area for pick-up and disposal by the DOE/RL.

\section{Air Pollution Control System}

The Air Pollution Control System will consist of a single wet electrostatic precipitator (WESP) system for particulate collection preceded by a venturi scrubber. The scrubber will remove large particulate from the flue gas stream as well as serve the function of reducing the flue gas temperature to protect the APCS components. Other equipment in the APCS consists of an air heater, HEPA filters, induced draft fan, and an exhaust stack.

After removal of small particles in the WESP, the temperature of the off-gas is raised in an off-gas heater prior to entering the HEPA filter for removal of fine particles. Redundant HEPA filters are used to facilitate maintenance. The off-gas exits the HEPA filters and flows from the system through the exhaust stack.

\section{Waste Water Treatment System}

The Demonstration Plant also includes a wastewater treatment system to remove radionuclides from the process water used in the venturi scrubber and WESP. This system consists of a clarifier, a filter press, sand filter, ion exchange unit, and various pumps and tanks.

Process water from the WESP flows through a wastewater tank, a chemical precipitation tank for chrome removal, and on to a clarifier. The solids from the clarifier, which contain some contaminants not captured in the glass, are dewatered in a filter press and are returned to the Feed Preparation System.

Radionuclides are removed by first filtering the supernate water in a sand bed. The solids are removed periodically from the sand bed by back flushing with the treated water, and the backwash is reintroduced into the clarifier. Radionuclides are removed through a combination of ion treatment and carbon bed filtering. The treated effluent is stored in a holding tank for reuse as quench water within the quencher/venturi scrubber.

\section{Process Monitoring and Control System}

The Process Monitoring and Control System consists of the sensors, electronics, instrumentation, computers, and redundant programmable logic controllers (PLC) to control the process in real time, gather data for analysis on system and equipment performance, and monitor process offgas. The control system will be automated to the maximum possible extent. Controllers shall be provided with the capability to be manually operated so that the combustion air blower and cooling water pumps can be operated in case of system failure. The system will be capable of being shut down in emergency situations in a controlled manner using the auxiliary power unit and structured logic. Proven industrial controls and electronics are used. Redundant PLCs enhance reliability. Multiple monitors are capable of being switched to allow individual subsystem processes to be monitored. In addition to collecting data for process and equipment evaluation, the system incorporates a Continuous Emissions Monitoring System for off-gas.

\subsubsection{Operations Description}

The demonstration plant will be installed and operated at a DOE facility that requires some form of soil remediation. To demonstrate the effectiveness of the technology, 400 hours of start-up and 
functional testing are planned, followed by a 30-day period of nearly continuous testing.

\subsubsection{Equipment List}

A summary of the major equipment discussed above is presented in Table 4.2-2.

\subsection{SCHEDULE}

Vortec has completed Phase 1 and nearing completion of Phase 2 of a three phase program to design construct and demonstrate the effectiveness of the CMS technology at remediating soils contaminated with both heavy metals and radionuclides. At the conclusion of Phase 2, the ability of the CMS to vitrify soils similar to the soil found at selected Hanford sites will have been demonstrated (this verification testing is already complete). The vitrified product passed the TCLP as well as the PCT for leachability of a glass being used to contain radionuclides. In addition, the final design of a 25 TPD demonstration plant to process contaminated soil is essentially completed. Phase 3 will carry out the construction of the plant and conduct the 30 days of demonstration testing. Figure 5.0-1 represents the tentative schedule for the completion of Phase 2 and Phase 3. 
Table 4.2-2. Summary of Equipment

\begin{tabular}{|c|c|}
\hline & DEMONSTRATION PLANT EQUTPMENT LLST \\
\hline \multicolumn{2}{|l|}{ EOUT } \\
\hline \multirow[t]{2}{*}{ No. } & IIing \\
\hline & 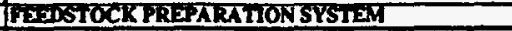 \\
\hline ME-TO & Coarse Scruener \\
\hline BE-101 & Feed Hopper \\
\hline ME-119 & Multiple Screw Feeder \\
\hline ME-102 & Wejob Bett Conveyor \\
\hline ME-10S & Rosiry Dryer \\
\hline ME-106 & Beh Conveyor \\
\hline ME-10\%. & Elag, Vene Dus Collector \\
\hline ME-108 ADB & Bide Ven HEPA Fileers \\
\hline ME-IOQ & Hor Dus Collector \\
\hline ME-113 & Grinding Mall \& Mall Bearing Lob. System \\
\hline MEIIS & Bercier Elevetor \\
\hline ME-116 & Feed cinsaliter \\
\hline ME-II7 AQB & Feed Preparzion of Ges HEPA Filler bank \\
\hline \multirow[t]{4}{*}{ ST-100 } & Feed Preparnoon Exhausr Stack \\
\hline & VITRMICATIONSYSIEM \\
\hline & TOLALBATCH \\
\hline & BATCHSYSTEM \\
\hline ME-123 & Glues Cullet Dust Collector \\
\hline $\mathrm{T}-102$ & Foluss Cullet Silo with Aeritor \\
\hline ME-126 & Glans Cullet Feeder \\
\hline T-IOT & Gles Cullet Transponter \\
\hline ME-124 & ISoda Ash Dust Colloctor \\
\hline$T \cdot 103$ & Sod4 Ash Stio with Aerutor \\
\hline ME-119 & Soda Ash Feeder \\
\hline$T-108$ & Sode Ach Transpones \\
\hline ME-125 & Limestone Dust Collector \\
\hline$T-104$ & Limestome Silo wich Aeritor \\
\hline$M E-120$ & Lirmentone Feeder \\
\hline$T \cdot 109$ & Limeslone Transponter \\
\hline ME-126 & Soil Dust Collectror \\
\hline T.105 & Soil Sllo with Aerator \\
\hline ME-12I & Soil Feeder \\
\hline T. $=110$ & Soil Transporter \\
\hline ME.127 & Batch Dust Callector \\
\hline$T \cdot T 06$ & Batch Blender \\
\hline ME-122 & Baxch Weight Feeder \\
\hline T-11I & Basch Transportuer \\
\hline $\mathrm{ME}-128$ & $\begin{array}{l}\text { Glending \& Batch Feed Compresced Aur Sya. } \\
\text { CoMBUS'TON MELTiNGSYSTIEM }\end{array}$ \\
\hline B-301 & CMS Combustion Air Blower \\
\hline ME-301 & CRV Combutior \\
\hline ME-302 & Cycione Meluer \\
\hline ME-303 & Separulorikeservoir \\
\hline ME-304 & Recuperions \\
\hline ME-305 & Recupenteor Plenass \\
\hline ME-306A\&B & Heat Up Burner \\
\hline & VITRHFIED PRODUCT HANDLINGSYSTEM \\
\hline ME-320 & Glass Quench Hen Exchanger \\
\hline ME-32I & Glass Quench Tank \\
\hline ME-322 & Dotas Conveyor \\
\hline P-320 A\&B & $\begin{array}{l}\text { Ouench Water Cinc. Pumps } \\
\text { AIR POLLUTION CONTROL SYSTEM }\end{array}$ \\
\hline ME- $4 \times 0$ & Spny Tower \\
\hline ME-407 & Spray Tower Cornpressed Air Sys. \\
\hline$P A 1) 1 A \& B$ & Spray Tower Booster Pumps \\
\hline$M E-4)$ & Process Dust Collector \\
\hline ME-S(X) & Ouencher Ventun Scrubber \\
\hline ME- 4 2 & Causte Feed Systero \\
\hline$M E-403$ & Acid Gas Absorter \\
\hline ME-SOI A\&B & Wet Electrostatic Precipitators (WESP) \\
\hline ME-40S & Process Off Gas Heater \\
\hline ME- 406 A\&B & Process off Gas HEPA Filter Bank \\
\hline$B A C O A \& B$ & Process Blower \\
\hline $5 T-400$ & Process Exhruust Stack \\
\hline & WASTEWATER TREATMENTSYSTEM \\
\hline$T-600)$ & Wastewater Tank \\
\hline$T-601 \mathrm{~A}, \mathrm{~B}, \& \mathrm{C}$ & Chemical Treament Taniss \\
\hline ME-G(Y) & Clarifier whth Sludge Serew Conveyor \\
\hline$T-603$ & Sludge Holding Tant \\
\hline ME-60I & Filuet Press \\
\hline ME-605 & Polvmer Biending System \\
\hline ME-602A.B.C & Polishing filter \\
\hline$M E-6) 3 A Q A B$ & Mixed Bed lon Exchange Units \\
\hline ME- $604 A \bar{R} B$ & Carbon Adsorber \\
\hline T-6UTS & Water Storage Tank \\
\hline & TUTLTIES \\
\hline ME-700 & Compressed Air System \\
\hline ME-701 & Cooling Tower \\
\hline$T-700$ & Liquid Propane Tank \\
\hline ME-702 & Propane Vaporizer \\
\hline & PROCESS MONTTORING AND CONTROL SYSTEM \\
\hline & Control Subsystem PLC \\
\hline & Data Acquisstion Subsystem Instrumenution \\
\hline & Continuous Emissions Monitoring Subsystem \\
\hline
\end{tabular}




\begin{tabular}{|c|c|c|c|c|c|c|c|c|c|c|c|c|c|c|c|c|c|c|c|c|c|c|c|c|c|c|}
\hline \multirow{3}{*}{ Activity } & \multicolumn{2}{|c|}{1994} & \multicolumn{12}{|c|}{1985} & \multicolumn{12}{|c|}{1996} \\
\hline & Nov & Doc & Jan & Fob & Mar & Apr & May & Jun & Jul & Aug & Sepp & Oat & Nov & Dec & Jan & Fob & Mar & Apr & May & Jun & Jut & Aug & Sopt & Oat & Nov & $\overline{D e c}$ \\
\hline & 14 & 15 & 16 & 17 & 18 & 19 & 20 & 21 & 22 & 23 & 24 & 25 & 26 & 27 & 28 & 29 & 30 & 31 & 32 & 33 & 34 & 35 & 36 & 37 & 38 & 39 \\
\hline PHASE 2 & & & & & & & & & & & & & & & & & & & & & & & & & & \\
\hline NEPA DOCUMENTATION (Complete) & & & & & & & & & & & & & & & & & & & & & & & & & & $\cdots$ \\
\hline PHASE 2 SITE SELECTION (Complete) & & & & & & & & & & & & & & & & & & & & & & & & & & \\
\hline SOIL CHARACTERIZZATION (Completo) & & & & & & & & & & & & & & & & & & & & & & & & & & - \\
\hline VERIFICATION TESTING... & & & & & & & & & & & & & & & & & & & & & & & & & & \\
\hline INTEG. SYSTEM DESIGN & & & & & & & & & & & & & & & & & & & & & & & & & & -1 \\
\hline PROIGRAM MANGEMENT & & & & & & & & & & & & & & & & & & & & & & & & & & $\ldots$ \\
\hline PHASE 3 & & & & & & & & & & & & & & & & & & & & & & & & & & 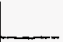 \\
\hline & & & & & & & & & & & & & & & & & & & & & & & & & & \\
\hline PROCUREMENT & & & & & & & & & & & & & & & & & & & & & & & & & & 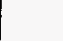 \\
\hline CONSTAUCTION & & & & & & & & & & & & & & & & & & & & & & & & & & \\
\hline SYSTEM TESTING & & & & & & & & & & & & & & - & & & & & & & & & & & & 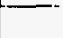 \\
\hline PHASE 4 DEFINITION & & & & & & & & & & & & & & & & & & & & & & & & & & - \\
\hline DECONTAM. \& DECOMMISS. & & & & & & & & & & & & & & & & & & & & & & & & & & -1 \\
\hline PROSECT MANAGEMENT & & & & & & & & & & & & & & & & & & & & & & & & & & - \\
\hline & & & & & & & & & & & & & & & & & & & & & & & & & & 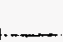 \\
\hline & & & & & & & & & & & & & & & & & & & & & & & & & & \\
\hline & & & & & & & & & & & & & & & & & & & & & & & & & & \\
\hline
\end{tabular}

Figure 5.0-1. METC Program Master Phasing Schedule 